\title{
2 Insulin in acute coronary syndrome: a narrative review with contemporary perspectives
}

3

4 Dr Michael CY Nam, BSc, MD, MRCP (UK) ${ }^{a}$

5 Prof Christopher D Byrne, PhD, FRCPath, FRCP ${ }^{\text {b }}$

6 Prof Juan Carlos Kaski, MD, DM (Hons), DSc, FRCP, FACC, FESC ${ }^{\mathrm{c}}$

7 Prof Kim Greaves, BSc, MD, FACC, FRCP (UK), FRACP ${ }^{\mathrm{a}}$

8

$9 \quad{ }^{a}$ Department of Cardiology, Sunshine Coast Hospital and Health Services, University of the 10 Sunshine Coast and University of Queensland, Queensland, Australia.

11

${ }^{\mathrm{b}}$ Nutrition \& Metabolism, Institute for Developmental Sciences, University of Southampton and Southampton National Institute for Health Research Biomedical Research Centre, University Hospital Southampton, Southampton General Hospital, Southampton, UK.

15

'Cardiovascular and Cell Sciences Research Institute, St George's University of London, 17 London, UK

Correspondence:

e:kim.greaves@health.qld.gov.au 


\section{Abstract}

2 The role of insulin in the treatment of acute coronary syndrome (ACS) has been widely studied over the past

3100 years. The current indication for its use in this context is the treatment of hyperglycemia, irrespective of

4 diabetes, which is associated with adverse outcome. Initial theories proposed that glucose was beneficial in

5 the context of myocardial ischemia and insulin was required to enable glucose cell uptake. However, studies testing this hypothesis with routine insulin administration during ACS have produced disappointing results and research interest has therefore declined. We propose that the less well known but important vasodilator effect of insulin has been overlooked by some of these studies and warrants further consideration. Previous reports have shown that hyperinsulinemic euglycaemia improves myocardial blood flow reserve. With this in mind, this review considers the role of insulin in the context of ACS from the perspective of a vasodilator rather than a

11 metabolic modulator. We discuss the importance of time to treatment, dosage of insulin administered, problems with hypoglycaemia and insulin resistance, and how they may have affected the outcomes of the major trials. Finally, we propose new study designs that allow determination of the optimal vasodilator conditions for the use of insulin as adjunctive pharmacotherapy during myocardial ischaemia.

21 AMI Acute Myocardial Infarction

22 IIT Intense Insulin Therapy

23 MBFR Myocardial Blood Flow Reserve

$24 \quad$ MBF Myocardial Blood Flow

25 HUVEC Human Umbilical Vein Endothelial Cells

26 STEMI ST Elevation Myocardial Infarction

27 PET Positron Emission Tomography

28 CAD Coronary Artery Disease

29 T2DM Type 2 Diabetes Mellitus 
2

\section{Conflicts of Interest}

4 The authors report no relationships that could be construed as a conflict of interest 
Hypo- and hyperglycemia (dysglycaemia) are common in acute coronary syndrome (ACS), and as such, improvement in blood glucose has been extensively studied as a potential therapeutic target. The current role of insulin therapy at the time of ACS is the regulation of blood glucose. This was consequent to the publication of the DIGAMI trial in 1997 which concluded that maintaining euglycaemia improved outcome [1]. However the majority of subsequent large-scale multi-centre trials employing strategies with much tighter blood glucose control and have involved over 25,000 patients in total, have generally failed to demonstrate any clinical benefit. The reasons for this are unclear but several theories, including the occurrence of hypoglycemia and hyperglycemia, have been suggested [2-5].

Trials utilising insulin in ACS have their basis centred around two beneficial mechanisms. Firstly, the addition of glucose, insulin, and potassium (GIK) therapy is believed to optimise fuel conditions for the heart and prevent arrhythmia during myocardial ischaemia [6]. Secondly, the regulation of blood glucose during myocardial ischemia in the form of intense insulin therapy (IIT) could prevent the detrimental effects of dysglycaemia. Our group demonstrated that an intravenous insulin infusion increases peak myocardial blood flow (MBF) by up to $30 \%$ [7]. Intuitively, in the setting of ACS, the vasodilator aspect of insulin should be beneficial as a form of adjunctive reperfusion therapy particularly in the immediate time period following primary angioplasty for STEMI. Insulin may also be helpful in mitigating the effects of the 'no-reflow' phenomenon which occurs in up to $50 \%$ of patients undergoing primary percutaneous coronary intervention (PCI) [8]. In the setting of NSTEMI, insulin's vasodilator effect may reduce ischemia by either increasing flow down the partially obstructed culprit vessel or by enhancing collateral flow. We therefore suggest consideration be given as to whether insulin's vasodilator rather than metabolic action has an important role to play in the context of myocardial ischemia $[9,10]$. The potent vasodilator effect of insulin on the myocardial vasculature is well described in the literature, yet this action is rarely credited as being of potential mechanistic benefit in the setting of ACS-related GIK and IIT studies [11-13]. Previous IIT and GIK trials were purposefully designed to exploit the metabolic benefits of insulin rather than its effect on microvascular function. This biochemically orientated approach could explain the negative outcomes in previous insulin-based ACS studies. If we accept the premise that insulin has a role as adjunctive reperfusion therapy then several aspects in trial design such as time to treatment and dosage, could have important mitigating effects. 
1 This review considers the role of insulin in the context of acute coronary syndromes from the perspective of a

2 vasodilator rather than metabolic action.

\section{Methodology}

We performed a systematic search (using PUBMED, EMBASE, Cochrane Central Register of Controlled Trials CENTRAL, and Google Scholar) for randomised trials and review articles from 1960 to November 2015 of the English literature regarding the use of insulin in ACS, and insulin's effect on myocardial blood flow. In order to identify and retrieve all potentially relevant articles regarding this topic, the search was performed utilizing the terms 'insulin', 'myocardial blood flow', 'myocardial infarction', 'coronary flow reserve' and 'acute coronary syndrome'. Articles perceived to be relevant to insulin use in ACS were selected for review. References of the studies could also be included in the analysis.

Glucose-insulin-potassium infusions during acute coronary syndromes

Metabolic modulation of acute myocardial infarction with glucose-insulin-potassium (GIK) infusion was originally proposed in the 1960's [14]. The concept is attractive because the therapy is simple, low cost and easily implemented. GIK infusions were thought to be potentially beneficial through several different mechanisms. Free fatty acids are normally the primary fuel source for the heart but are toxic to the myocardium in the ischemic setting causing sarcolemmal and mitochondrial membrane disruption [15]. Exogenous insulin was known to suppress circulating levels of free fatty acids and also prevent their uptake by the myocardium $[16,17,15]$. Provision of high-dose glucose was thought to improve the efficiency of myocardial energy production during acute ischemia by becoming the preferred fuel source for the heart. Intracellular levels of potassium are depleted during ischemia and therefore the provision of exogenous potassium to increase levels within the myocyte were believed to raise the threshold for ventricular arrhythmias $[18,19]$. An overview by Fath-Ordoubadi in 1997 resulted in a revival of interest in GIK administration for treating acute myocardial infarction (AMI) [20]. The first study in the post-thrombolytic era to investigate this concept was the ECLA-GIK pilot trial in 1998 [21]. This study randomised patients with suspected AMI to low or high dose GIK following admission. They found that there was a significant $66 \%$ reduction in mortality in those patients who received both high-dose GIK and reperfusion strategies compared to reperfusion alone. Importantly, this was driven by an unexpectedly high mortality rate in the control arm 
$1 \quad(\mathbf{1 5 \% )}$ which the authors attributed to the small cohort. Nonetheless this re-stimulated great interest in GIK

2 therapy in ACS and a further 10 trials have taken place since, one of which did not reach completion, and

3 another was an analysis of two studies combined (see tables 1 and 2). Study design varied considerably with

4 regards insulin infusion dosage and regulation of blood glucose parameters. Overall, a total of 26,855 patients have been recruited with studies ranging from the small (120 patients) to the very large (over 20,000). The results have been disappointingly conflicting. Two studies have shown a benefit in primary end-point with evidence in favour of GIK (total 525 patients)[21,22], seven showed no difference (25,496 patients)[23-29], and one showed increased harm (954 patients) [30].

\section{Intensive insulin therapy during acute coronary syndromes}

Several studies have demonstrated that in-patient hyperglycemia is associated with a significant increase in mortality in ACS. It was therefore thought that improved glycemic control in ACS would relate to improved outcomes. The Diabetes Mellitus Insulin-Glucose Infusion in Acute Myocardial Infarction (DIGAMI) was the first study to investigate this hypothesis [1]. This study randomised patients with DM presenting with an AMI to receive either intensive insulin therapy (IIT) or conventional treatment for hyperglycemia. After 1-year, a significant $29 \%$ relative risk reduction in all-cause mortality was observed with IIT. As a result of this landmark study, national guidelines were changed recommending that IIT should be used to control elevated blood glucose in those patients presenting with ACS and hyperglycemia. Insulin-based glycemic control for patients following ACS is now widespread and common practice in the Western world [31]. In line with this thinking, subsequent studies were undertaken to examine whether a narrower range of glucose control would translate into lower mortality rates. Three separate studies involving almost a total of 1800 patients have since been undertaken (tables 1 and 2) [32-34]. The method of IIT differed significantly between studies: HI-5 regulated blood glucose between 4 - 10mmol, DIGAMI-2 opted for ongoing glucose regulation using subcutaneous insulin following intravenous infusion, and RECREATE targeted lower blood glucose during intravenous insulin infusion. However all have failed to show any significant benefit with regard to improved blood glucose control and primary endpoints. 
1 Intensive insulin therapy and glucose-insulin-potassium infusions lack efficacy in acute coronary syndromes

2 Since DIGAMI there have been thirteen clinical trials investigating the effect of GIK infusions and IIT in ACS

3 (Tables 1 and 2). Apart from three, all have failed to show any convincing significant benefit and two actual

4 harm. The reasons for the failure of these studies to demonstrate clinical benefit is unclear but several theories have been postulated. The foremost is that hypoglycaemia in the insulin-treated groups may be having an adverse effect. Several studies have associated hypoglycaemia (plasma glucose $\leq 3.9 \mathrm{mmol} / \mathrm{l}$ ) with an increase in cardiovascular mortality, including those following an ACS [35,36]. Hypoglycemia, either symptomatic or biochemical, is a frequent occurrence in the insulin arm, ranging from 10-22\% (see tables 1 and 2 for hypoglycemia occurence in studies). Hypoglycemia has been demonstrated to have a number of adverse physiological effects, including the induction of a hypercoagulant state, an inflammatory response, QT prolongation and a detrimental effect on cardiac metabolism because of the inability of the heart to use glucose $[37,38]$.

Myocardial blood flow reserve (MBFR) is the ratio of MBF at peak hyperaemia to that at rest, and, in the context of unobstructed coronary arteries, is a measure of microcirculatory function. Peak hyperaemia is usually achieved by the administration of a vasodilator drug such as adenosine or dipyridamole. Values of MBFR in healthy individuals is usually $>2.0$ [39]. Our group (see fig.1) demonstrated that insulin-induced hypoglycaemia was associated with a 14\% reduction in MBFR with respect to baseline values in both type 1 diabetics and healthy controls [2]. We suggested that the reduction in blood flow occurring during hypoglycaemia might be detrimental in the context of ACS. Importantly, we also noted that hyperinsulinemic euglycemia (insulin infused at $1.5 \mathrm{mU} / \mathrm{Kg} / \mathrm{min}$ ) was associated with a $22 \%$ increase in MBFR above baseline. This increase in myocardial blood flow by hyperinsulinemia had also been observed in other previous human studies. In 1997, Rogers et al reported a $12 \%$ increase in coronary sinus blood flow in patients with suspected ischaemic heart disease who received a GIK infusion [11]. A further study found that local intracoronary insulin infusion increased coronary sinus blood flow, suggesting a direct insulin-mediated effect [12]. Sundell et al observed that higher blood insulin levels resulted in greater increases in myocardial blood flow [40]. 
1 literature, this action is rarely credited as being of potential mechanistic benefit in the setting of ACS-related

2 GIK and IIT studies. Furthermore, the mechanism by which insulin induces vasodilation is not fully understood

3 but is thought to be mediated through nitric oxide release [12]. Sobrevia performed the first in vitro study to

4 examine this association by monitoring L-arginine transport - a precursor for nitric oxide production - into

5 human umbilical vein endothelial cells (HUVECs) [41]. When HUVECs were incubated with insulin under conditions of euglycaemia $(5 \mathrm{mmol} / \mathrm{L})$ there was a 2.5 -fold increase in the transport of the amino acid L-arginine (a precursor for nitric oxide production via nitric oxide synthase) into the HUVECs. They also noted a 3-fold increase in intracellular cyclic guanosine monophospate (cGMP) concentrations - an index of nitric oxide synthesis. This data demonstrated that insulin led to an endothelium-dependent release of nitric oxide and this was suggested to be the mechanism behind insulin-induced vasodilatation.

Insulin: vasodilator and metabolic actions in acute coronary syndromes

Intuitively, in the setting of ACS, the vasodilator aspect of insulin should be beneficial as a form of adjunctive reperfusion therapy. We must therefore consider whether insulin's vasodilator action also has an important role to play in the context of myocardial ischemia. Previous IIT and GIK trials were designed to exploit the metabolic benefits of insulin rather than its effect on microvascular function. Thus it is worth re-examining from a reperfusion stand-point, how the biochemically adopted approach in trial design, could have affected outcomes with previous insulin-based ACS studies. Thus, if insulin's vasodilator action is important as adjunctive reperfusion therapy then the following aspects in trial design could have a significant effect:

1. Time delay to initiation of insulin therapy following acute myocardial ischemia.

2. Optimum treatment dose with insulin therapy to achieve maximum vasodilator effect.

3. Prevalence of hypoglycaemia.

\section{Time delay to initiation of insulin therapy in IIT and GIK ACS studies}

It is well established that the mortality following AMI is directly related to infarct size. Infarct size is directly related to the area of ischemic myocardium at risk and the duration of ischemia. For the past 40 years, clinical 
most rapid and complete manner possible. This has been achieved with great success using biological clot dissolution (thrombolysis) and, has been superseded by mechanical means (primary angioplasty). It is well established that any delay in reperfusion therapy is directly related to an adverse outcome and that 'time is muscle' [42].

Out of the 14 reports on IIT and GIK, the times from onset of chest pain to administration of IIT and GIK ranged from 55 minutes to $19 \mathrm{hrs}$. In the DIGAMI study, insulin was given 'within 24hrs' [1]. Furthermore, because either median or mean values are consistently quoted this means that a significant percentage of patients received insulin therapy beyond that time frame. For example, in the largest study (CREATE-ECLA) of 20,000 patients with ST-elevation myocardial infarction (STEMI), the median time to randomisation was 4.7hrs resulting in $20 \%$ of patients receiving GIK $8-12 \mathrm{hrs}$ after symptom onset [25]. In the REVIVAL study, $25 \%$ of patients received insulin therapy more than $18 \mathrm{hrs}$ after symptom onset [24]. The IMMEDIATE trial administered fixed-dose GIK infusions out-of-hospital and achieved a median treatment initiation time of 1.3 hours after symptom onset [29]. However only $\mathbf{5 0 \%}$ of enrolled patients resulted in a final diagnosis of ACS suggesting that many patients had alternate diagnoses, and this may have inadvertently affected outcome. Nevertheless, in sub-group analysis of the STEMI population, there was a significant reduction in composite outcome of cardiac arrest and 1-year mortality.

Clearly if insulin therapy is to be successful as an adjunctive reperfusion therapy, treatment needs to be given as quickly as possible and within a minimum timeframe. The wide range of times to treatment in all of the above trials may have had an important confounding effect.

Suboptimal treatment dose with insulin therapy to achieve maximum vasodilator effect The doses of insulin therapy in the GIK and IIT trials varied considerably, with some protocols containing high and low dose arms, and others titrating insulin infusion rates according to blood glucose. Where data was available, the mean insulin infusion rate (in $\mathrm{mU} / \mathrm{kg} / \mathrm{min}$ ) for each major trial was calculated and presented in tables 1 and 2. Our group demonstrated that $1.5 \mathrm{mU} / \mathrm{kg} / \mathrm{min}$ insulin is able to increase peak $\mathrm{MBF}$ by $30 \%$ compared to without [7]. This dose compares favourably with the findings of Sundell [40]. He showed that an insulin infusion of $1.0 \mathrm{mU} / \mathrm{kg} / \mathrm{min}$ and $5 \mathrm{mU} / \mathrm{kg} / \mathrm{min}$ produced a $19 \%$ and $44 \%$ increase in adenosine-induced peak hyperemic MBF respectively. In the post-DIGAMI GIK and IIT studies the doses infused ranged between 
$1[1,30,22,28,21,33,34]$, and two did not report their infusion rates $[23,43]$. Clearly, it is possible that the

2 hyperemic effect of insulin in myocardial ischemia may have to be above a certain value to be effective and

3 that, for example, doses lower than $1 \mathrm{mU} / \mathrm{kg} / \mathrm{min}$ may not be sufficient.

4

High prevalence of hypoglycemia during IIT and GIK studies Hypoglycaemia, which reduces MBF, occurred frequently in the treatment arms of the GIK and IIT studies and ranged from 0 to $23 \%$ (see tables 1 and 2). However, in 5 studies the rates were not mentioned at all $[28,26,27,29,21]$. Some studies recorded symptomatic hypoglycaemia only (not biochemical) and this would significantly underestimate true biochemical hypoglycemia $[22,25]$. Furthermore, the frequency of glucose measurements varied widely, with three studies only measuring blood glucose three times within a 24-hour period and are therefore likely to have missed episodes of hypoglycemia $[22,25,26]$.

\section{The role of insulin resistance}

Insulin resistance is present in patients with type 2 diabetes (T2DM) and also those patients with metabolic syndrome. The prevalence of T2DM within the ACS-related GIK and IIT trials ranged from 6-39\%, and was prerequisite for all patients participating in the DIGAMI-2 trial [32]. Central abdominal obesity (BMI $>30 \mathrm{~kg} / \mathrm{m}^{2}$ ) which forms a major parameter of the 'pre-diabetes' metabolic syndrome is associated with insulin resistance [44]. Obesity was prevalent in over $23 \%$ of patients in insulin-related ACS trials, implying that metabolic syndrome and therefore insulin resistance was also present $[22,32,23]$. In fact, a recent study identified that insulin resistance in non-diabetics was diagnosed in $60-70 \%$ of their STEMI cohort [45]. The results of studies investigating the effect of insulin resistance on MBF have been conflicting. Quantitative assessment of MBF using PET in 167 angina patients found IR to be an independent predictor of reduced hyperaemic MBF [46]. Another study demonstrated a diminished MBF response to exogenous insulin administration in obese subjects using both physiological and supra-physiological hyperinsulinemia regimens [47]. In contrast however, Sondergaard using PET, reported no difference in hyperemic MBF between T2DM and non-diabetics with coronary artery disease, in response to hyperinsulinemia [48]. If we consider that insulin resistance does indeed impair insulin's vasodilatory effect on MBF, then this may explain at least in part the disappointing 

syndrome and T2DM.

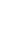

results in some of the GIK and IIT ACS studies which contained a significant number of patients with metabolic

\section{The effects of insulin infusion on myocardial ischemia - what has gone before and what is not known}

Human studies investigating whether an infusion of insulin (whilst maintaining normoglycemia) can improve MBF within ischemic myocardium, have been limited and inconclusive. Marano examined the effect of a GIK infusion on peak MBF but this was 24 hours after a completed infarct [49]. The group showed that although there was improvement in flow, this was confined to the segments adjacent to the infarcted area. BucciarelliDucci et al administered 24-hour GIK infusions on STEMI patients initiated prior to undergoing primary PCI. GIK infusion was found to be associated with improved myocardial blush grade which is used as an angiographic marker of myocardial reperfusion after PCI [50]. These two studies add further argument that timely administration of such therapies predict myocardial salvage. There have also been studies undertaken during the 1970's in patients with ischemic heart disease but these produced conflicting and unreliable results [51,52]. In general, they used small numbers, were observational and had little or no statistical power. Furthermore, the assessment of ischemia was indirect, using symptoms, ECG and end-diastolic pressure changes. Large bolus doses of both insulin and glucose were also given which often caused transient and severe hyperglycemia (>30mmol). This may be important because in STEMI patients, hyperglycemia is a strong predictor of impaired coronary flow prior to primary PCl [53].

Specifically, there have been two studies, both in 2006, looking at the effects of hyperinsulinemic euglycemia on MBF in patients with ischemic heart disease $[54,48]$. All subjects had stable angina with documented significant CAD, rather than ACS. Each study produced conflicting results to the other. Using the vasodilator (adenosine) PET to assess MBF, Lautamaki investigated the effects of hyperinsulinemic euglycemia in 47 patients with significant CAD and T2DM [54]. Insulin was infused at $1 \mathrm{mU} / \mathrm{kg} / \mathrm{min}$ for 60 minutes with the result that MBF to the ischemic regions was improved by $20 \%$ compared to without insulin. However, the vasodilator flow assessments (with and without insulin) were performed within a single session and always in this set order: placebo infusion followed by insulin infusion. This methodological strategy could have inadvertently induced a pre-conditioning effect and reduced ischemic burden in the insulin-based arm [55]. Sondergaard examined 27 patients with CAD, of whom 12 had T2DM [48]. She reported that hyperinsulinemic euglycemia ( $1 \mathrm{mU} / \mathrm{kg} / \mathrm{min}$ infused for $\mathbf{2}$ hours) had no effect on hyperaemic MBF in the ischemic regions. 
1 However they did not show increased flow in the healthy regions either, which is surprising as this feature has

2 been consistently demonstrated in other studies.

3 Importantly, neither study found an increase in area of myocardial ischemia. This 'coronary steal phenomenon'

4 can theoretically occur when maximal vasodilatation of resistance vessels occurs in non-ischemic regions with

5 diversion of blood away from underperfused regions where the vasodilator reserve has been exhausted [56].

6 This phenomenon could potentially worsen myocardial ischaemia, but it should be pointed out that insulin has not been demonstrated to elicit this response in either animal or human studies. In summary therefore, the effect of hyperinsulinemic euglycemia on patients with myocardial ischemia is not known.

Future Research

11 The potential confounding factors that may offset the beneficial therapeutic effects of hyperinsulinaemia during ischaemia are summarised in figure 2 . We recommend that any future studies should initially address these before any further large trials examining the vasodilatory effects of hyperinsulinaemia in myocardial ischemia are undertaken. Larger randomised control trials could then be designed to assess the effects of acute insulin therapy in ACS from the perspective of adjunctive reperfusion therapy.

\section{Conclusion}

Exploration of the potential benefits of insulin therapy in the context of acute coronary syndrome has been extensively studied over the last 50 years. Although the initial studies showed promise, later studies have been surprisingly disappointing in terms of clinical outcome. This may be because previous trials have been designed around the metabolic modulatory aspects of insulin, and have overlooked its potent vasodilator effect. As a result, delay in initiation of therapy, insufficient insulin dose, insulin resistance and hypoglycemia may all have had important mitigating effects in terms of outcome. We recommend detailed studies determining the optimum conditions for insulin's vasodilator effect on myocardial blood flow before any further large-scale ACS trials involving insulin are undertaken.

\section{Acknowledgements}


2 CDB is supported in part by the Southampton National Institute for Health Research Biomedical Research 3 Centre.

4

5

6 
Table 1: Studies that showed benefit of insulin in ACS

\begin{tabular}{|c|c|c|c|c|c|c|c|}
\hline Study & $\begin{array}{l}\text { Treatment } \\
\text { strategy }\end{array}$ & Design & Outcomes & $\begin{array}{l}\text { Occurence of } \\
\text { hypoglycaemia } \\
\text { (\%) }\end{array}$ & $\begin{array}{c}\text { Type } 2 \\
\text { diabetes } \\
(\%)\end{array}$ & $\begin{array}{l}\text { Insulin dose } \\
(\mathrm{mU} / \mathrm{kg} / \mathrm{min})^{\dagger}\end{array}$ & $\begin{array}{l}\text { Time from } \\
\text { symptom onset } \\
\text { to treatment } \\
\text { (hrs) }\end{array}$ \\
\hline $\begin{array}{l}\text { DIGAMI } \\
1997 \text { [1] }\end{array}$ & GR & $\begin{array}{l}620 \text { patients (mean age } 68 \text { ) with ACS } \\
\text { and blood glucose }>11 \mathrm{mmol} / \mathrm{I} \\
\text { randomised IIT for } \geq 24 \text { hours followed } \\
\text { by long-term subcutaneous insulin vs } \\
\text { usual care. }\end{array}$ & $\begin{array}{l}\text { 1-year mortality } \\
\text { significantly lower in the } \\
\text { IIT arm ( } 19 \text { vs } 26 \% \text {, relative } \\
\text { reduction } 30 \%, p=0.027 \text { ). } \\
\text { In patients not previously } \\
\text { on insulin and low } \\
\text { cardiovascular risk, in- } \\
\text { hospital mortality was } \\
\text { significantly lower ( } 5 \% \text { vs } \\
12 \%, \text { relative reduction } \\
58 \%, p<0.05 \text { ). }\end{array}$ & 15 & 82 & $\begin{array}{l}1.2 \text { first hour } \\
\text { then titrated to } \\
\text { glucose }\end{array}$ & $\begin{array}{c}\text { Mean (SD) } 13 \\
\text { (7) }\end{array}$ \\
\hline $\begin{array}{l}\text { ECLA-GIK } \\
\text { Pilot } \\
1998 \\
{[21]}\end{array}$ & GIK & $\begin{array}{l}405 \text { patients with ACS (mean age } 58 \text { ) } \\
\text { randomised to } 24 \text {-hours high vs low } \\
\text { dose GIK infusion vs usual care. }\end{array}$ & $\begin{array}{l}62 \% \text { received reperfusion } \\
\text { therapy ( } 95 \% \\
\text { thrombolysis, } 5 \% \mathrm{PCI}) \text {. No } \\
\text { significant difference in in- } \\
\text { hospital mortality between } \\
\text { groups. In subgroup } \\
\text { analysis GIK plus } \\
\text { reperfusion group had } \\
\text { lower mortality (5 vs } 15 \% \\
\mathrm{p}=0.01) \text {. Composite } \\
\text { endpoint of death, non- } \\
\text { fatal ventricular } \\
\text { fibrillation, and heart }\end{array}$ & Not mentioned & $15^{\ddagger}$ & $\begin{array}{l}\text { High dose } 1.3 . \\
\text { Low dose } 0.5 .\end{array}$ & $\begin{array}{c}\text { Mean (SD) } 11 \\
(0.56)\end{array}$ \\
\hline
\end{tabular}

${ }^{\dagger}$ Estimated based on $70 \mathrm{~kg}$ subject

${ }^{\ddagger}$ Includes type 1 diabetes as proportion not given

ACS Acute Coronary Syndrome

IIT Intense Insulin Therapy

GIK Glucose-Insulin-Potassium therapy

GR Glucose regulation

STEMI ST-Elevation Myocardial Infarction

PCI - Percutaneous Coronary Intervention 
failure was lower in GIK

group ( 12 vs $20 \% \mathrm{p}=0.03$ )

\begin{tabular}{|c|c|c|c|c|c|c|c|}
\hline $\begin{array}{l}\text { GIPS-1 } \\
2003 \\
{[23]}\end{array}$ & GIK and GR & $\begin{array}{l}940 \text { patients (mean age } 60 \text { ) presenting } \\
\text { with STEMI eligible for reperfusion } \\
\text { therapy were randomised to GIK } \\
\text { infusion vs usual care prior to } \\
\text { revascularisation. }\end{array}$ & $\begin{array}{l}\text { No significant difference in } \\
30 \text {-day mortality, but } \\
\text { patients who received GIK } \\
\text { without clinical heart } \\
\text { failure had lower } 30 \text {-day } \\
\text { mortality ( } 1.2 \text { vs } 4.2 \% \\
p=0.01) \text {. }\end{array}$ & 0 & $11^{\ddagger}$ & $\begin{array}{l}\text { Dose titrated } \\
\text { glucose 7- } \\
11 \mathrm{mmol} / \mathrm{L} \text {. }\end{array}$ & $\begin{array}{c}\text { Median (IQR) } \\
3(2,4) .\end{array}$ \\
\hline $\begin{array}{l}\text { Krlijanac } \\
2005 \\
{[22]}\end{array}$ & GIK & $\begin{array}{l}120 \text { patients with STEMI received } \\
\text { thrombolytic therapy and randomised } \\
\text { to GIK infusion vs usual care. }\end{array}$ & $\begin{array}{l}\text { Major adverse cardiac } \\
\text { events (MACE), defined as } \\
\text { a composite of cardiac } \\
\text { death, reinfarction, } \\
\text { malignant arrhythmias, } \\
\text { and severe heart failure at } \\
\text { 1-month and 1-year, was } \\
\text { lower in GIK group at 1- } \\
\text { month ( } 10 \% \text { vs } 33 \% \\
\mathrm{p}=0.004) \text { and } 1 \text {-year ( } 13 \% \\
\text { vs } 40 \%, p=0.001) \text {. }\end{array}$ & 2 & $17^{\ddagger}$ & 0.8 & Mean (SD) 3(2) \\
\hline
\end{tabular}


Table 2: Studies that showed no benefit from insulin in ACS

\begin{tabular}{|c|c|c|c|c|c|c|c|}
\hline Study (Year) & Treatment strategy & Design & Outcomes & $\begin{array}{l}\text { Hypoglycaemia } \\
(\%)\end{array}$ & $\begin{array}{c}\text { Type } 2 \\
\text { Diabetes } \\
\text { (\%) }\end{array}$ & $\begin{array}{l}\text { Insulin dose } \\
(\mathrm{mU} / \mathrm{kg} / \mathrm{min})^{\S}\end{array}$ & $\begin{array}{c}\text { Time from } \\
\text { symptom onset } \\
\text { to treatment } \\
(\mathrm{hrs})\end{array}$ \\
\hline $\begin{array}{l}\text { POL-GIK } \\
\text { (1999) [30] }\end{array}$ & GIK & $\begin{array}{l}954 \text { patients with chest } \\
\text { pain and 'ischaemic } \\
\text { ECG' within 24-hours } \\
\text { were randomised to } \\
\text { GIK vs saline for 24- } \\
\text { hours plus usual care. }\end{array}$ & $\begin{array}{l}\text { ACS confirmed in } 88 \% .60 \% \\
\text { received fibrinolysis. Non-cardiac } \\
\text { mortality was higher in GIK group } \\
\text { ( } 11.1 \text { vs } 6.5 \% \mathrm{p}=0.01) \text {. Causes of } \\
\text { non-cardiac mortality were } \\
\text { stroke, GI bleeding, and } \\
\text { neoplastic disease. Cardiac } \\
\text { death, resuscitated cardiac } \\
\text { arrest, congestive heart failure, } \\
\text { reinfarction, arrhythmia, and } \\
\text { angiography at } 35 \text { days were no } \\
\text { different between groups. }\end{array}$ & 7.6 & 6.5 & 0.3 & $\begin{array}{c}\text { Median (IQR) } 5 \\
(3,10)\end{array}$ \\
\hline $\begin{array}{l}\text { REVIVAL } \\
(2004) \text { [24] }\end{array}$ & GIK & $\begin{array}{l}312 \text { patients with ACS } \\
\text { (80\% STEMI) within } 48 \\
\text { hours randomised to } \\
\text { 24-hour infusion of GIK } \\
\text { vs control. Myocardial } \\
\text { perfusion scintigraphy } \\
\text { was performed at } \\
\text { baseline and } 2 \text { weeks } \\
\text { to compare myocardial } \\
\text { salvage in infarct } \\
\text { territory-matched }\end{array}$ & $\begin{array}{l}98 \% \text { received reperfusion } \\
\text { therapy ( } 89 \% \mathrm{PCI} \text { and } 11 \% \\
\text { thrombolysis). } 15 \% \text { did not } \\
\text { complete GIK infusion due to } \\
\text { adverse events. Myocardial } \\
\text { salvage was not improved by } \\
\text { insulin overall, but subgroup } \\
\text { analysis showed diabetics had } \\
\text { improved myocardial salvage } \\
\text { index. There was no difference in } \\
\text { 6-month mortality. }\end{array}$ & Not mentioned & $23 * *$ & 1.2 & $\begin{array}{c}\text { Median (IQR) } 9 \\
(3,18)\end{array}$ \\
\hline
\end{tabular}

\footnotetext{
${ }^{\S}$ Estimated based on $70 \mathrm{~kg}$ subject

${ }^{* * *}$ Includes type 1 diabetes as proportion not given

ACS Acute Coronary Syndrome

GIK Glucose-Insulin-Potassium

GR Glucose regulation

STEMI ST Elevation Myocardial Infarction

PCI Percutaneous Coronary Intervention
} 


\begin{tabular}{|c|c|c|c|c|c|c|c|}
\hline & & patients. & & & & & \\
\hline $\begin{array}{l}\text { DIGAMI-2 } \\
(2005)[32]\end{array}$ & $\begin{array}{l}\text { GR (target 7-10 } \\
\mathrm{mmol} / \mathrm{l} \text { ) }\end{array}$ & $\begin{array}{l}1253 \text { patients with } \\
\text { type-2 diabetes or } \\
\text { glucose }>11 \mathrm{mmol} / \mathrm{I} \\
\text { with suspected ACS } \\
\text { were randomised to } \\
\text { 24-hour infusion of } \\
\text { insulin-glucose } \\
\text { followed by } \\
\text { subcutaneous insulin } \\
\text { or standard glucose } \\
\text { control vs usual care. }\end{array}$ & $\begin{array}{l}84 \% \text { had confirmed myocardial } \\
\text { infarction ( } 44 \% \text { had STEMI). } \\
\text { Mortality at } 2 \text { years was no } \\
\text { different between groups. } \\
\text { Secondary endpoints of stroke } \\
\text { and reinfarction were also no } \\
\text { different. }\end{array}$ & 11 & 100 & $\begin{array}{l}1.2 \text { first hour } \\
\text { then titrated to } \\
\text { blood glucose }\end{array}$ & $\begin{array}{c}\text { Mean (SD) } \\
13(7)\end{array}$ \\
\hline $\begin{array}{l}\text { CREATE- } \\
\text { ECLA (2005) } \\
{[25]}\end{array}$ & GIK & $\begin{array}{l}20201 \text { patients with } \\
\text { STEMI randomised to } \\
24 \text {-hour infusion of GIK } \\
\text { vs usual care. }\end{array}$ & $\begin{array}{l}9 \% \text { received } \mathrm{PCl} .74 \% \text { received } \\
\text { thrombolysis. No significant } \\
\text { difference between groups in } 30- \\
\text { day mortality. No difference in } \\
\text { cardiac arrest, cardiogenic shock, } \\
\text { composite death/nonfatal } \\
\text { cardiac arrest. Insulin group } \\
\text { displayed no benefit in pre- } \\
\text { specified subgroups, including } \\
\text { strata of time from symptom to } \\
\text { randomisation, killip class, type } \\
\text { of reperfusion therapy, diabetes } \\
\text { status, and baseline glucose. }\end{array}$ & 0.4 & 18 & 1.3 & $\begin{array}{c}\text { Median (IQR) } 5 \\
(3,7)\end{array}$ \\
\hline $\begin{array}{l}\text { GIPS-II } \\
(2006) \text { [28] }\end{array}$ & GIK and GR & $\begin{array}{l}889 \text { patients with } \\
\text { STEMI eligible for } \\
\text { reperfusion therapy } \\
\text { without heart failure } \\
\text { randomised to GIK } \\
\text { infusion for } 12 \mathrm{hrs} \text { vs nil } \\
\text { plus usual care. }\end{array}$ & $\begin{array}{l}94 \% \text { received reperfusion } \\
\text { therapy }(88 \% \text { primary } \mathrm{PCI}) . \text { There } \\
\text { was no significant } 30 \text {-day } \\
\text { mortality benefit in the insulin } \\
\text { group. }\end{array}$ & Not mentioned & 6 & $\begin{array}{l}\text { Titrated but } \\
\text { mean } 2.3(\text { SD } 1.8) \\
\text { in first hour }\end{array}$ & Not mentioned \\
\hline $\begin{array}{l}\text { Hi-5 (2006) } \\
{[33]}\end{array}$ & $\begin{array}{l}\text { GR (target 4-10 } \\
\mathrm{mmol} / \mathrm{l})\end{array}$ & $\begin{array}{l}240 \text { patients with acute } \\
\text { myocardial infarction } \\
\text { within } 24 \mathrm{hrs} \text { and either }\end{array}$ & $\begin{array}{l}72 \% \text { had STEMI. } 68 \% \text { received } \\
\text { reperfusion therapy. In-hospital, } \\
\text { 3-month, and 6-month mortality }\end{array}$ & 10 & 39 & $\begin{array}{l}0.5 \text { first hour } \\
\text { then titrated }\end{array}$ & $\begin{array}{c}\text { Mean (SD) } \\
13(8)\end{array}$ \\
\hline
\end{tabular}




\begin{tabular}{|c|c|c|c|c|c|c|c|}
\hline & & $\begin{array}{l}\text { known diabetes or } \\
\text { glucose }>7.8 \mathrm{mmol} / / \\
\text { randomised to insulin } \\
\text { infusion } \geq 24 \mathrm{hrs} \text { vs } \\
\text { conventional } \\
\text { treatment. }\end{array}$ & $\begin{array}{l}\text { were not significantly different } \\
\text { between groups. } \\
\text { The insulin group had lower } \\
\text { incidence of in-hospital cardiac } \\
\text { failure }(13 \% \text { vs } 23 \%, p=0.04 \text { ) and } \\
\text { reinfarction within } 3 \text { months ( } 2 \% \\
\text { vs } 6 \%, p=0.05 \text { ) }\end{array}$ & & & & \\
\hline $\begin{array}{l}\text { OASIS-6 } \\
(2007)[26]\end{array}$ & GIK & $\begin{array}{l}2748 \text { patients with } \\
\text { STEMI randomised to } \\
\text { 24-hour GIK infusion vs } \\
\text { usual care. }\end{array}$ & $\begin{array}{l}42 \% \text { received thrombolysis, and } \\
32 \% \text { received } \mathrm{PCI} \text {. No significant } \\
\text { difference between groups in } 30- \\
\text { day outcomes of death, heart } \\
\text { failure, or composite death/heart } \\
\text { failure. No difference in } 6 \text {-month } \\
\text { heart failure, composite heart } \\
\text { failure/death, myocardial } \\
\text { infarction, stroke, cardiogenic } \\
\text { shock, and cardiac arrest. }\end{array}$ & Not mentioned & 15 & 1.3 & Not mentioned \\
\hline $\begin{array}{l}\text { Combined } \\
\text { OASIS-6 + } \\
\text { CREATE } \\
\text { ECLA } \\
\text { analysis } \\
(2007)[27]\end{array}$ & GIK & $n=22943$ & $\begin{array}{l}\text { No significant difference } \\
\text { between groups in } 30 \text {-day } \\
\text { mortality, heart failure, or } \\
\text { composite death/heart failure. } \\
\text { In subanalysis days } 0-3 \text {, mortality } \\
\text { and composite death/heart } \\
\text { failure was increased in the } \\
\text { insulin treated group ( } 6.2 \% \text { vs } \\
5.5 \% \text { p }=0.03 \text {, and } 15.8 \% \text { vs } 14.5 \% \\
p=0.02 \text {, respectively). } \\
\text { Hyperglycaemia, hyperkalaemia, } \\
\text { and high Kilip class predicted } \\
\text { adverse outcome. }\end{array}$ & Not mentioned & 17 & 1.3 & Not mentioned \\
\hline
\end{tabular}




\begin{tabular}{|c|c|c|c|c|c|c|c|}
\hline $\begin{array}{l}\text { IMMEDIATE } \\
(2012)[29] \\
++\end{array}$ & GIK & $\begin{array}{l}871 \text { pre-hospital } \\
\text { patients with } \\
\text { suspected ACS } \\
\text { randomised to GIK } \\
\text { infusion vs } 5 \% \text { - } \\
\text { dextrose placebo. }\end{array}$ & $\begin{array}{l}50 \% \text { progressed to myocardial } \\
\text { infarction. } 41 \% \text { with STEMI and } \\
47 \% \text { undergoing primary PCl. } \\
\text { Progression to } \mathrm{Ml} \text { and } 30-\text { day } \\
\text { mortality was no different } \\
\text { between groups. Composite } \\
\text { endpoint of cardiac arrest and in- } \\
\text { hospital mortality was lower in } \\
\text { insulin group ( } 4.4 \% \text { vs } 8.7 \% \text {, } \\
\mathrm{p}=0.01 \text { ). }\end{array}$ & Not mentioned & $29 * *$ & 1.3 & $\begin{array}{c}\text { Median (IQR) } \\
1.5(1,3)\end{array}$ \\
\hline $\begin{array}{l}\text { RECREATE } \\
(2012)[34]\end{array}$ & $\begin{array}{l}\text { GR (target 5-6.5 } \\
\mathrm{mmol} / \mathrm{I})\end{array}$ & $\begin{array}{l}287 \text { patients with } \\
\text { STEMI within } 24 \text { hours } \\
\text { onset and blood } \\
\text { glucose }>8 \mathrm{mmol} / \mathrm{l} \\
\text { randomised to IIT vs } \\
\text { usual care. }\end{array}$ & $\begin{array}{l}77 \% \text { received thrombolysis, and } \\
14 \% \text { received } \mathrm{PCI} .30 \text {-day all } \\
\text { cause mortality were similar in } \\
\text { both groups( } \sim 9 \%) . \text { Reinfarction, } \\
\text { stroke, congestive heart failure, } \\
\text { and rehospitalisation were no } \\
\text { different between groups. }\end{array}$ & 23 & $30 * *$ & $\begin{array}{l}\text { Titrated to blood } \\
\text { glucose. Mean } \\
0.5 \mathrm{mU} / \mathrm{kg} / \mathrm{min}(\mathrm{SD} \\
0.3) \text { in } 24 \mathrm{hrs}\end{array}$ & $\begin{array}{c}\text { Median (IQR) } \\
10(6,18)\end{array}$ \\
\hline
\end{tabular}

** Includes type 1 diabetes as proportion not given

ACS Acute Coronary Syndrome

GIK Glucose-Insulin-Potassium therapy

GR Glucose Regulation

STEMI ST Elevation Myocardial Infarction

PCI Percutaneous Coronary Intervention 


\section{Figure Legends}

Figure 1. Myocardial blood flow reserve (MBFR) at baseline and during hyperinsulinemic euglycemia (HE) and hyperinsulinemic hypoglycemia $(\mathrm{HH})$. In healthy controls HE increases MBFR 22\% above baseline, whereas HH reduces MBFR 14\% below baseline (both $p<0.0001$ ). There was a similar effect in diabetics. Solid circles, healthy control subjects; solid squares, type 1 diabetes mellitus patients (mean \pm SD)[7].

Figure 2. Diagram illustrating the effects of insulin on myocardial ischaemia and potential confounding factors. 


\section{References}

1. Malmberg K (1997) Prospective randomised study of intensive insulin treatment on long term survival after acute myocardial infarction in patients with diabetes mellitus. DIGAMI (Diabetes Mellitus, Insulin Glucose Infusion in Acute Myocardial Infarction) Study Group. BMJ 314 (7093):1512-1515

2. Rana OA, Byrne CD, Greaves K (2014) Intensive glucose control and hypoglycaemia: a new cardiovascular risk factor? Heart 100 (1):21-27. doi:10.1136/heartjnl-2013-303871

3. Vriesendorp TM, van Santen S, DeVries JH, de Jonge E, Rosendaal FR, Schultz MJ, Hoekstra JB (2006) Predisposing factors for hypoglycemia in the intensive care unit. Crit Care Med 34 (1):96101

4. Kosiborod M, Inzucchi SE, Krumholz HM, Xiao L, Jones PG, Fiske S, Masoudi FA, Marso SP, Spertus JA (2008) Glucometrics in patients hospitalized with acute myocardial infarction: defining the optimal outcomes-based measure of risk. Circulation 117 (8):1018-1027. doi:10.1161/circulationaha.107.740498

5. van der Horst IC, Nijsten MW, Vogelzang M, Zijlstra F (2007) Persistent hyperglycemia is an independent predictor of outcome in acute myocardial infarction. Cardiovasc Diabetol 6:2. doi:10.1186/1475-2840-6-2

6. Opie LH, Jonnessen A, Yellon DM (2004) The glucose hypothesis: updated or outdated? Role of insulin. . Cardiovasc J S Afr 15:S1

7. Rana O BC, Kerr D, Coppini D, Zouwail S, Senior R, Begley J, Walker JJ, Greaves K (2011) Acute Hypoglycaemia Decreases Myocardial Blood Flow Reserve in Patients With Type 1 Diabetes Mellitus and in Healthy Humans. Circulation 124:1548-1556 
8. Durante A, Camici PG (2015) Novel insights into an "old" phenomenon: the no reflow. International journal of cardiology 187:273-280. doi:10.1016/j.ijcard.2015.03.359

9. van der Horst IC, Zijlstra F (2005) Potential beneficial mechanisms of insulin (glucosepotassium) in acute myocardial infarction. Neth Heart J 13 (6):233-238

10. Sundell J KJ (2003) Insulin and myocardial blood flow. Cardiovascular Research 57:312-319 11. Rogers WJ, Russell RO, Jr., McDaniel HG, Rackley CE (1977) Acute effects of glucose-insulinpotassium infusion on myocardial substrates, coronary blood flow and oxygen consumption in man. Am J Cardiol 40 (3):421-428

12. McNulty PH, Pfau S, Deckelbaum LI (2000) Effect of plasma insulin level on myocardial blood flow and its mechanism of action. Am J Cardiol 85 (2):161-165

13. Legtenberg RJ, Houston RJ, Oeseburg B, Smits P (2002) Physiological insulin concentrations protect against ischemia-induced loss of cardiac function in rats. Comp Biochem Physiol A Mol Integr Physiol 132 (1):161-167

14. Sodi-Pallares D, Testelli MR, Fishleder BL, Bisteni A, Medrano GA, Friedland C, De Micheli A (1962) Effects of an intravenous infusion of a potassium-glucose-insulin solution on the electrocardiographic signs of myocardial infarction. A preliminary clinical report. Am J Cardiol 9:166-181

15. Oliver MF, Kurien VA, Greenwood TW (1968) Relation between serum-free-fatty acids and arrhythmias and death after acute myocardial infarction. Lancet 1 (7545):710-714

16. Oliver MF, Opie LH (1994) Effects of glucose and fatty acids on myocardial ischaemia and arrhythmias. Lancet 343 (8890):155-158

17. Opie LH, Tansey M, Kennelly BM (1977) Proposed metabolic vicious circle in patients with large myocardial infarcts and high plasma-free-fatty-acid concentrations. Lancet 2 (8044):890892 
18. Brown MJ, Brown DC, Murphy MB (1983) Hypokalemia from beta2-receptor stimulation by circulating epinephrine. NEJM 309 (23):1414-1419. doi:10.1056/nejm198312083092303 19. Obeid Al, Verrier RL, Lown B (1978) Influence of glucose, insulin, and potassium on vulnerability to ventricular fibrillation in the canine heart. Circ Res 43 (4):601-608

20. Fath-Ordoubadi F, Beatt KJ (1997) Glucose-insulin-potassium therapy for treatment of acute myocardial infarction: an overview of randomized placebo-controlled trials. Circulation 96 (4):1152-1156

21. Diaz R, Paolasso EA, Piegas LS, Tajer CD, Moreno MG, Corvalan R, Isea JE, Romero G (1998) Metabolic modulation of acute myocardial infarction. The ECLA (Estudios Cardiologicos Latinoamerica) Collaborative Group. Circulation 98 (21):2227-2234

22. Krljanac G, Vasiljevic Z, Radovanovic M, Stankovic G, Milic N, Stefanovic B, Kostic J, Mitrovic P, Radovanovic N, Dragovic M, Marinkovic J, Karadzic A (2005) Effects of glucose-insulinpotassium infusion on ST-elevation myocardial infarction in patients treated with thrombolytic therapy. Am J Cardiol 96 (8):1053-1058. doi:10.1016/j.amjcard.2005.05.068

23. van der Horst IC, Zijlstra F, van 't Hof AW, Doggen CJ, de Boer MJ, Suryapranata H, Hoorntje JC, Dambrink JH, Gans RO, Bilo HJ (2003) Glucose-insulin-potassium infusion inpatients treated with primary angioplasty for acute myocardial infarction: the glucose-insulin-potassium study: a randomized trial. JACC 42 (5):784-791

24. Pache J, Kastrati A, Mehilli J, Bollwein H, Ndrepepa G, Schuhlen H, Martinoff S, Seyfarth M, Nekolla S, Dirschinger J, Schwaiger M, Schomig A (2004) A randomized evaluation of the effects of glucose-insulin-potassium infusion on myocardial salvage in patients with acute myocardial infarction treated with reperfusion therapy. Am Heart J 148 (1):e3.

doi:10.1016/j.ahj.2004.01.019 
25. Mehta SR, Yusuf S, Diaz R, Zhu J, Pais P, Xavier D, Paolasso E, Ahmed R, Xie C, Kazmi K, Tai J, Orlandini A, Pogue J, Liu L (2005) Effect of glucose-insulin-potassium infusion on mortality in patients with acute ST-segment elevation myocardial infarction: the CREATE-ECLA randomized controlled trial. JAMA 293 (4):437-446. doi:10.1001/jama.293.4.437

26. Yusuf S, Mehta SR, Chrolavicius S, Afzal R, Pogue J, Granger CB, Budaj A, Peters RJ, Bassand JP, Wallentin L, Joyner C, Fox KA (2006) Effects of fondaparinux on mortality and reinfarction in patients with acute ST-segment elevation myocardial infarction: the OASIS-6 randomized trial. JAMA 295 (13):1519-1530. doi:10.1001/jama.295.13.joc60038

27. Diaz R, Goyal A, Mehta SR, Afzal R, Xavier D, Pais P, Chrolavicius S, Zhu J, Kazmi K, Liu L, Budaj A, Zubaid M, Avezum A, Ruda M, Yusuf S (2007) Glucose-insulin-potassium therapy in patients with ST-segment elevation myocardial infarction. JAMA 298 (20):2399-2405. doi:10.1001/jama.298.20.2399

28. Timmer JR, Svilaas T, Ottervanger JP, Henriques JP, Dambrink JH, van den Broek SA, van der Horst IC, Zijlstra F (2006) Glucose-insulin-potassium infusion in patients with acute myocardial infarction without signs of heart failure: the Glucose-Insulin-Potassium Study (GIPS)-II. JACC 47 (8):1730-1731. doi:10.1016/j.jacc.2006.01.040

29. Selker HP, Beshansky JR, Sheehan PR, Massaro JM, Griffith JL, D'Agostino RB, Ruthazer R, Atkins JM, Sayah AJ, Levy MK, Richards ME, Aufderheide TP, Braude DA, Pirrallo RG, Doyle DD, Frascone RJ, Kosiak DJ, Leaming JM, Van Gelder CM, Walter GP, Wayne MA, Woolard RH, Opie LH, Rackley CE, Apstein CS, Udelson JE (2012) Out-of-hospital administration of intravenous glucose-insulin-potassium in patients with suspected acute coronary syndromes: the IMMEDIATE randomized controlled trial. JAMA 307 (18):1925-1933. doi:10.1001/jama.2012.426 30. Ceremuzynski L, Budaj A, Czepiel A, Burzykowski T, Achremczyk P, Smielak-Korombel W, Maciejewicz J, Dziubinska J, Nartowicz E, Kawka-Urbanek T, Piotrowski W, Hanzlik J, Cieslinski A, 
Kawecka-Jaszcz K, Gessek J, Wrabec K (1999) Low-dose glucose-insulin-potassium is ineffective in acute myocardial infarction: results of a randomized multicenter Pol-GIK trial. Cardiovasc Drugs Ther 13 (3):191-200

31. Deedwania P, Kosiborod M, Barrett E, Ceriello A, Isley W, Mazzone T, Raskin P (2008) Hyperglycemia and acute coronary syndrome: a scientific statement from the American Heart Association Diabetes Committee of the Council on Nutrition, Physical Activity, and Metabolism. Circulation 117 (12):1610-1619. doi:10.1161/circulationaha.107.188629

32. Malmberg K, Ryden L, Wedel H, Birkeland K, Bootsma A, Dickstein K, Efendic S, Fisher M, Hamsten A, Herlitz J, Hildebrandt P, MacLeod K, Laakso M, Torp-Pedersen C, Waldenstrom A (2005) Intense metabolic control by means of insulin in patients with diabetes mellitus and acute myocardial infarction (DIGAMI 2): effects on mortality and morbidity. Eur Heart J 26 (7):650-661. doi:10.1093/eurheartj/ehi199

33. Cheung NW, Wong VW, McLean M (2006) The Hyperglycemia: Intensive Insulin Infusion in Infarction (HI-5) study: a randomized controlled trial of insulin infusion therapy for myocardial infarction. Diabetes Care 29 (4):765-770

34. Nerenberg KA, Goyal A, Xavier D, Sigamani A, Ng J, Mehta SR, Diaz R, Kosiborod M, Yusuf S, Gerstein HC (2012) Piloting a novel algorithm for glucose control in the coronary care unit: the RECREATE (REsearching Coronary REduction by Appropriately Targeting Euglycemia) trial.

Diabetes Care 35 (1):19-24. doi:10.2337/dc11-0706

35. Kosiborod M, Rathore SS, Inzucchi SE, Masoudi FA, Wang Y, Havranek EP, Krumholz HM (2005) Admission glucose and mortality in elderly patients hospitalized with acute myocardial infarction: implications for patients with and without recognized diabetes. Circulation 111 (23):3078-3086. doi:10.1161/circulationaha.104.517839 
36. Pinto DS, Skolnick AH, Kirtane AJ, Murphy SA, Barron HV, Giugliano RP, Cannon CP, Braunwald E, Gibson CM (2005) U-shaped relationship of blood glucose with adverse outcomes among patients with ST-segment elevation myocardial infarction. JACC 46 (1):178-180. doi:10.1016/j.jacc.2005.03.052

37. Trovati M, Anfossi G, Cavalot F, Vitali S, Massucco P, Mularoni E, Schinco P, Tamponi G, Emanuelli G (1986) Studies on mechanisms involved in hypoglycemia-induced platelet activation. Diabetes 35 (7):818-825

38. Suys B, Heuten S, De Wolf D, Verherstraeten M, de Beeck LO, Matthys D, Vrints C, Rooman R (2006) Glycemia and corrected QT interval prolongation in young type 1 diabetic patients: what is the relation? Diabetes Care $29(2): 427-429$

39. Camici PG, Crea F (2007) Coronary microvascular dysfunction. NEJM 356 (8):830-840. doi:10.1056/NEJMra061889

40. Sundell J, Nuutila P, Laine H, Luotolahti M, Kalliokoski K, Raitakari O, Knuuti J (2002) Dosedependent vasodilating effects of insulin on adenosine-stimulated myocardial blood flow. Diabetes $51(4): 1125-1130$

41. Sobrevia L, Nadal A, Yudilevich DL, Mann GE (1996) Activation of L-arginine transport (system $\mathrm{y}^{+}$) and nitric oxide synthase by elevated glucose and insulin in human endothelial cells. J Physiol 490 ( Pt 3):775-781

42. Weaver WD, Cerqueira M, Hallstrom AP, Litwin PE, Martin JS, Kudenchuk PJ, Eisenberg M (1993) Prehospital-initiated vs hospital-initiated thrombolytic therapy. The Myocardial Infarction Triage and Intervention Trial. JAMA 270 (10):1211-1216 43. SWEET-ACS: intensified multifactorial intervention on hyperglycemic patients with acute coronary syndromes (trial did not complete) (2007). https://wwwclinicaltrialsregistereu/ctrsearch/trial/2007-000543-98/ITed 
44. Despres JP (2012) Abdominal obesity and cardiovascular disease: is inflammation the missing link? Can J Cardiol 28 (6):642-652. doi:10.1016/j.cjca.2012.06.004

45. Lexis CP, van der Horst-Schrivers AN, Lipsic E, Valente MA, Muller Kobold AC, de Boer RA, van Veldhuisen DJ, van der Harst P, van der Horst IC (2015) The effect of metformin on cardiovascular risk profile in patients without diabetes presenting with acute myocardial infarction: data from the Glycometabolic Intervention as adjunct to Primary Coronary Intervention in ST Elevation Myocardial Infarction (GIPS-III) trial. BMJ Open Diabetes Res Care 3 (1):e000090. doi:10.1136/bmjdrc-2015-000090

46. Liga R RD, Sampietro T, Vecoli C, Todiere G, Caselli C, Rossi G, L'Abbate A, Neglia D (2013) Insulin resistance is a major determinant of myocardial blood flow impairment in anginal patients. Eur J Nucl Med Mol Imaging 40:1905-1913

47. Sundell J, Laine H, Luotolahti M, Kalliokoski K, Raitakari O, Nuutila P, Knuuti J (2002) Obesity affects myocardial vasoreactivity and coronary flow response to insulin. Obes Res 10 (7):617624. doi:10.1038/oby.2002.84

48. Sondergaard HM, Bottcher M, Marie Madsen M, Schmitz O, Hansen SB, Nielsen TT, Botker HE (2006) Impact of type 2 diabetes on myocardial insulin sensitivity to glucose uptake and perfusion in patients with coronary artery disease. J Clin Endocrinol Metab 91 (12):4854-4861. doi:10.1210/jc.2006-1416

49. Marano L, Bestetti A, Lomuscio A, Tagliabue L, Castini D, Tarricone D, Dario P, Tarolo GL, Fiorentini C (2000) Effects of infusion of glucose-insulin-potassium on myocardial function after a recent myocardial infarction. Acta Cardiol 55 (1):9-15

50. Bucciarelli-Ducci C, Bianchi M, De Luca L, Battagliese A, Di Russo C, Proietti P, Vizza CD, Fedele F (2006) Effects of glucose-insulin-potassium infusion on myocardial perfusion and left 
ventricular remodeling in patients treated with primary angioplasty for ST-elevation acute myocardial infarction. Am J Cardiol 98 (10):1349-1353. doi:10.1016/j.amjcard.2006.06.025 51. Lesch M, Teichholz LE, Soeldner JS, Gorlin R (1974) Ineffectiveness of glucose, potassium, and insulin infusion during pacing stress in chronic ischemic heart disease. Circulation 49 (6):1028-1037

52. Thadani U, Chiong MA, Parker JO (1979) Effects of glucose-insulin-potassium infusion on the angina response during treadmill exercise. Cardiology 64 (6):333-349

53. Timmer JR, Ottervanger JP, de Boer M-J, Dambrink J-HE, Hoorntje JCA, Gosselink ATM, Suryapranata H, Zijlstra F, van't Hof AWJ, Zwolle Myocardial Infarction Study G (2005) Hyperglycemia is an important predictor of impaired coronary flow before reperfusion therapy in ST-segment elevation myocardial infarction. JACC 45 (7):999-1002. doi:10.1016/j.jacc.2004.12.050

54. Lautamaki R, Airaksinen KE, Seppanen M, Toikka J, Harkonen R, Luotolahti M, Borra R, Sundell J, Knuuti J, Nuutila P (2006) Insulin improves myocardial blood flow in patients with type 2 diabetes and coronary artery disease. Diabetes 55 (2):511-516

55. Yellon DM, Downey JM (2003) Preconditioning the myocardium: from cellular physiology to clinical cardiology. Physiol Rev 83 (4):1113-1151. doi:10.1152/physrev.00009.2003

56. Duncker DJ, Bache RJ (2000) Regulation of coronary vasomotor tone under normal conditions and during acute myocardial hypoperfusion. Pharmacol Ther 86 (1):87-110 